\title{
MUSKMELON SEED GERMINATION AND SEEDLING DEVELOPMENT IN RESPONSE TO SEED PRIMING
}

\author{
Warley Marcos Nascimento \\ Embrapa Hortaliças, C.P.218-CEP: 70359-970-Brasília, DF. CNPq Fellow.e-mail <wmn@cnph.embrapa.br>
}

ABSTRACT: Important factors affecting seed priming have not been extensively reported in muskmelon (Cucumis melo L.) studies. The optimization of the seed priming technique becomes very important at the commercial scale. Little information has been reported on seedling development of muskmelon subsequent to seed priming. Seeds of muskmelon were primed in darkness at $25^{\circ} \mathrm{C}$ in different solutions and three osmotic potentials. Seeds were also primed with and without aeration during different periods. In relation to osmotic solutions, an osmotic potential around $-1.30 \mathrm{MPa}$ is most adequate for muskmelon priming. Salt solutions gave better germination rate but were deleterious for seed germination, especially at higher osmotic potentials. Aeration of the soaking salt solution gave faster germination at $17^{\circ} \mathrm{C}$, and because of the early germination, these treatments probably presented a better seedling development. Deleterious effect on total seed germination was observed for long soaking periods with aeration. Fungal growth increased on seeds primed in aerated solutions. Seeds from priming treatments had a better germination rate and seedling development under 17 and $25^{\circ} \mathrm{C}$.

Key words: Cucumis melo, osmoconditioning, stand establishment

\section{GERMINAÇÃO DE SEMENTES E DESENVOLVIMENTO DE PLÂNTULAS DE MELÃO EM RESPOSTA AO CONDICIONAMENTO OSMÓTICO}

\begin{abstract}
RESUMO: Importantes fatores afetando o condicionamento osmótico não têm sido extensivamente relatados em sementes de melão (Cucumis melo L.). A otimização do condicionamento osmótico é extremamente importante em uma escala comercial. Poucas informações têm sido relatadas quanto ao desenvolvimento de plântulas em resposta ao condicionamento osmótico de sementes de melão. Sementes de melão foram condicionadas a $25^{\circ} \mathrm{C}$, na ausência de luz, em diferentes soluções osmóticas utilizando três potenciais osmóticos para cada solução. Em outro estudo, sementes foram condicionadas com ou sem aeração durante vários períodos. Indiferentemente das soluções osmóticas, o potencial osmótico em torno de - 1,30 MPa foi mais adequado para o condicionamento osmótico. Sementes condicionadas em soluções salinas germinaram mais rápido, mas apresentaram redução na porcentagem de germinação, principalmente nos potenciais osmóticos mais altos. A aeração das soluções salinas acelerou a germinação das sementes a $17^{\circ} \mathrm{C} \mathrm{e}$, provavelmente devido a germinação mais rápida, estes tratamentos mostraram um melhor desenvolvimento das plântulas. Efeitos deletérios na germinação foram observados em sementes que foram condicionadas em soluções aeradas por períodos mais prolongados. Foi observado ainda maior crescimento de fungos em sementes condicionadas em soluções aeradas. Sementes condicionadas germinaram mais rápido e originaram plântulas mais desenvolvidas tanto a 17 como a $25^{\circ} \mathrm{C}$ quando comparadas com as sementes não condicionadas.
\end{abstract}

Palavras-chave: Cucumis melo, estabelecimento de plântulas

\section{INTRODUCTION}

Seed priming (osmoconditioning, osmopriming, osmotic priming) is a pre-sowing treatment that involves exposure of seeds to a low external water potential that limits hydration. This hydration is sufficient to permit pregerminative metabolic events but insufficient to allow radicle protrusion through the seed coat (Heydecker et al., 1975). This technique has become a common seed treatment that can increase rate, percentage and uniformity of germination or seedling emergence, mainly under unfavorable environmental conditions.

Several studies reported the benefits of muskmelon (Cucumis melo L.) seed priming on germination at low temperatures (Nerson \& Govers, 1986;
Bradford et al., 1988; Dhillon, 1995; Nascimento \& West, 2000). Commercial utilization and availability of primed seeds to farmers is still small. One reason for the low use of primed seeds is inconsistency in germination performance (Parera \& Cantliffe, 1994). The optimization of the seed priming technique becomes important, especially at the commercial scale. Several factors affect seed priming response: solution composition and osmotic potential, the duration and temperature, and the extent of aeration. Muskmelon has been primed in $\mathrm{KNO}_{3}$ (Bradford et al., 1988), $\mathrm{KH}_{2} \mathrm{PO}_{4}+\mathrm{KNO}_{3}$ (Nerson \& Govers, 1986), $\mathrm{NaCl}$ (Akers et al., 1985), mannitol (Passam et al., 1989), and polyethylene glycol (PEG) (Yeoung et al., 1996). Although the response to priming is strongly dependent on the osmotic potential of the 
solution (Bradford, 1986; Smith \& Cobb, 1991), osmotic potential was not cited in most of these studies. The duration of seed priming is critical and was reported for many crops (Bradford, 1986). Final seedling emergence of carrot, for instance, decreased as priming duration increased (Murray, 1989). Seeds of pepper primed in PEG for six days produced more abnormal seedlings than seeds primed for four or five days (Cantliffe et al., 1981). In muskmelon studies, seeds have been primed from 16 hours (Dhillon, 1995) to ten days (Yeoung et al., 1996). Adequate oxygen is required during seed priming (Heydecker et al., 1975; Bujalski et al., 1989). Some reports recommend aeration during priming of melon seeds (Bradford et al., 1988; Nerson \& Govers, 1986), whereas others indicate deleterious effects (Akers et al., 1985). Aeration of the solution reduces the time needed for lettuce seed priming (Guedes \& Cantliffe, 1980).

To better understand the priming technique applied to muskmelon, this study screened several priming solutions of different osmotic potentials, to investigate the need for aeration of the soaking solution and to clarify the correlation between aeration and soaking period duration.

\section{MATERIAL AND METHODS}

Experiment 1: One lot of muskmelon cv. Mission seeds (Asgrow Seed Co, San Juan Bautista, CA) was primed in darkness at $25^{\circ} \mathrm{C}$ for six days, in five aerated solutions ( $10 \mathrm{~mL}$ of solution $\mathrm{g}^{-1}$ of seed), using two osmotic potentials (Table 1 ). A third osmotic potential for each solution ranging from -0.8 to $-0.9 \mathrm{MPa}$ was also used, but these treatments were discarded due to the high number of germinated seeds during the soaking period. The osmotic potential at $25^{\circ} \mathrm{C}$ of each solution was determined with a Wescor 5130 B Vapor Pressure Osmometer (Wescor Inc., Logan, Utah). Solution aeration was provided by an aquarium pump. The air was moistened by bubbling through water to minimize evaporation of the priming solution. The solution was changed every other day. After the six-day period, seeds were rinsed in running tap water $(2 \mathrm{~min})$ and then dried at $25 \pm 2^{\circ} \mathrm{C}$ and $50 \% \mathrm{RH}$ for four days. Seed moisture after priming and drying was determined by the oven method $\left(104^{\circ} \mathrm{C} / 24 \mathrm{~h}\right)$. Four replications of 50 primed and nonprimed seeds were placed in petri dishes containing two germination papers and $10 \mathrm{~mL}$ of deionized water and incubated in a germination chamber, in darkness, at 17 or $25^{\circ} \mathrm{C}$. Radicle protrusion was scored daily. After 7 and 10 days of incubation, seedlings were evaluated for abnormality (AOSA, 1993). Shoot and root fresh weights and lengths were measured at 5 and 10 days. All data were subjected to analysis of variance.

Experiment 2: Seeds from the same lot were primed for $3,6,9$ and 12 days in darkness at $25^{\circ} \mathrm{C}$ in
$\mathrm{KNO}_{3}(\Psi=-1.4 \mathrm{MPa})$ solution $\left(10 \mathrm{~mL}\right.$ of solution $\mathrm{g}^{-1}$ of seed). Seeds were either aerated as described in Experiment 1 or not aerated, which formed a $4 \times 3$ factorial of priming duration and aeration. The solution was changed every other day. Rinsing and drying procedures were the same as in Experiment 1. Seed germination and seedling growth data at 17 or $25^{\circ} \mathrm{C}$ were collected and analyzed as described in Experiment 1. Four replications of 50 seeds were used in each treatment using a complete randomized design. Analysis of variance and factorial analysis were performed using the Statistical Analysis System.

\section{RESULTS AND DISCUSSION}

Experiment 1: The seed moisture content (SMC) after soaking on the different priming treatments ranged from 39.4 to $45.0 \%$ (Table 1). Generally, SMC during priming is maintained between $40-45 \%$, which is equivalent to maintain the seeds in a state where it is at approximately $90-95 \%$ of the SMC that could allow germination (Bray, 1995). The amount of water taken up by seeds during soaking was dependent on the osmotic solution. In salt solutions, seeds tended to absorb more water than in seeds primed in mannitol or PEG, corroborating wilt the results obtained in other studies (Guedes et al., 1979). After drying, SMC decreased to $5.5-6.1 \%$ (before priming, the initial SMC was $5.8 \%$ ). Seeds primed in all osmotic solutions with osmotic potential varying from -0.8 to $-0.9 \mathrm{MPa}$ germinated during soaking (data not shown), and were discarded. Carpenter \& Boucher (1991) reported similar results in pansy seeds primed in a $-0.8 \mathrm{MPa}$ PEG solution.

Priming increased the germination rate for both temperatures (Table 2), although it was more evident for $17^{\circ} \mathrm{C}$. Thus, seed priming overcame the inhibitory effect of low temperatures and increased germination and the

Table 1 - Muskmelon seed moisture content after priming in different osmotic solutions and osmotic potentials, and after drying.

\begin{tabular}{lrrcc}
\hline \multirow{2}{*}{$\begin{array}{l}\text { Osmotic } \\
\text { solution }\end{array}$} & Concentration $\begin{array}{c}\text { Osmotic } \\
\text { potential }\end{array}$ & \multicolumn{2}{c}{$\begin{array}{c}\text { Mfter } \\
\text { Priming }\end{array}$} & $\begin{array}{c}\text { After } \\
\text { Drying }\end{array}$ \\
\hline $\mathrm{KNO}_{3}$ & $\mathrm{~mol} \mathrm{~L}^{-1}$ & $-\mathrm{MPa}$ & $-------\%$ & ------- \\
& 0.30 & 1.06 & 44.9 & 5.5 \\
$\mathrm{KH}_{2} \mathrm{PO}_{4}$ & 0.35 & 1.29 & 45.0 & 5.7 \\
& 0.30 & 1.14 & 43.6 & 5.9 \\
$\mathrm{KNO}_{3}{ }^{+}$ & 0.40 & 1.27 & 44.7 & 6.1 \\
$\mathrm{KH}_{2} \mathrm{PO}_{4}$ & $0.15+0.15$ & 1.18 & 43.6 & 5.7 \\
$\mathrm{Mannitol}$ & $0.20+0.20$ & 1.32 & 43.2 & 5.7 \\
$\mathrm{PEG}$ & 0.50 & 1.27 & 43.3 & 6.0 \\
& 0.60 & 1.36 & 42.7 & 5.7 \\
\hline
\end{tabular}

Original seed moisture content $=5.8 \%$. 
stand establishment in the field. In general, the effects of seed priming on muskmelon seed germination have been mainly observed at sub-optimal conditions (Bradford, 1985; Bradford, 1986), and this was confirmed by our results. Priming in salt solutions lead to faster germination than priming in mannitol or PEG. Similar results were also observed for tomato and pepper seeds primed in $\mathrm{KNO}_{3}$ and $\mathrm{KNO}_{3}+\mathrm{K}_{3} \mathrm{PO}_{4}$ solutions (Alvarado et al., 1987; O'Sullivan \& Bouw, 1984). However, priming in salt solutions reduced germination percentage, especially at higher osmotic potentials ( -1.06 to $-1.18 \mathrm{MPa}$ ) (Table 2). Germination percentages of leek and carrot seeds were lower

Table 2 - Muskmelon seed germination percentage and germination rate at 17 and $25^{\circ} \mathrm{C}$ in response to priming at different osmotic solutions and osmotic potentials.

\begin{tabular}{|c|c|c|c|c|c|}
\hline \multirow{3}{*}{$\begin{array}{l}\text { Osmotic } \\
\text { Solution }\end{array}$} & \multirow{3}{*}{$\begin{array}{c}\text { Osmotic } \\
\text { Potential } \\
-\mathrm{MPa}\end{array}$} & \multicolumn{4}{|c|}{ Temperature $\left({ }^{\circ} \mathrm{C}\right)$} \\
\hline & & \multicolumn{2}{|c|}{17} & \multicolumn{2}{|c|}{25} \\
\hline & & MGR $^{*}$ & Germ. & MGR & Germ. \\
\hline & & days & $\%$ & days & $\%$ \\
\hline \multirow[t]{2}{*}{$\mathrm{KNO}_{3}$} & 1.06 & $3.25 \mathrm{a}^{* *}$ & $77.5 \mathrm{~cd}$ & $1.05 \mathrm{a}$ & 81.2 b \\
\hline & 1.29 & $3.32 \mathrm{a}$ & $97.5 \mathrm{a}$ & $1.0 \mathrm{a}$ & $91.2 \mathrm{ab}$ \\
\hline \multirow[t]{2}{*}{$\mathrm{KH}_{2} \mathrm{PO}_{4}$} & 1.14 & $4.19 \mathrm{~b}$ & $83.7 \mathrm{bc}$ & $1.14 \mathrm{ab}$ & $88.7 \mathrm{ab}$ \\
\hline & 1.27 & $4.16 \mathrm{~b}$ & $97.5 \mathrm{a}$ & $1.0 \mathrm{a}$ & $100.0 \mathrm{a}$ \\
\hline \multirow[t]{2}{*}{$\begin{array}{l}\mathrm{KNO}_{3}+ \\
\mathrm{KH}_{2} \mathrm{PO}_{4}\end{array}$} & 1.18 & $4.45 \mathrm{bc}$ & $61.2 \mathrm{~d}$ & $1.15 \mathrm{ab}$ & $63.7 \mathrm{c}$ \\
\hline & 1.32 & $3.40 \mathrm{a}$ & $95.0 \mathrm{a}$ & $1.03 \mathrm{a}$ & $93.7 \mathrm{ab}$ \\
\hline \multirow[t]{2}{*}{ Mannitol } & 1.27 & $4.46 \mathrm{bc}$ & $91.2 a b$ & $1.31 \mathrm{bc}$ & $100.0 \mathrm{a}$ \\
\hline & 1.36 & $5.08 \mathrm{~cd}$ & $95.0 \mathrm{a}$ & $1.17 \mathrm{ab}$ & $98.7 \mathrm{a}$ \\
\hline \multirow[t]{2}{*}{ PEG } & 1.16 & $5.40 \mathrm{~d}$ & $96.2 \mathrm{a}$ & $1.46 \mathrm{c}$ & $100.0 \mathrm{a}$ \\
\hline & 1.53 & $5.71 \mathrm{de}$ & $100.0 \mathrm{a}$ & $1.84 \mathrm{~d}$ & $100.0 \mathrm{a}$ \\
\hline $\begin{array}{l}\text { Nonprim- } \\
\text { ed }\end{array}$ & - & $6.38 \mathrm{e}$ & $93.7 \mathrm{a}$ & $1.85 \mathrm{~d}$ & $100.0 \mathrm{a}$ \\
\hline
\end{tabular}

* MGR $=$ average number of days to germinate.

** Values within a column followed by the same letter are not different $(P=0.05)$, according to Duncan's multiple range test. following priming in salt solutions (e.g., $\mathrm{KH}_{2} \mathrm{PO}_{4}$ ) than in PEG 6000 (Brocklehurst \& Dearman, 1984). lons from salt solutions may penetrate the muskmelon seed during priming and cause decreased seed germination. Muskmelon seeds are, however, not damaged by imbibition in salt solutions because some ions $\left(\mathrm{K}^{+}\right.$or other ions of similar hydrated size) are excluded from the embryo by the perisperm envelope (endosperm + perisperm) Welbaum \& Bradford (1989).

Seedling shoot and root fresh weights and lengths were higher at $25^{\circ} \mathrm{C}$ than at $17^{\circ} \mathrm{C}$ germination temperature (Table 3 ). Beneficial effects of priming on seedling growth were more evident at $17^{\circ} \mathrm{C}$ than $25^{\circ} \mathrm{C}$ and in those treatments (e.g., salt solutions) which presented better germination rate, suggesting that priming does not accelerate seedling growth per se. The major effects of seed priming on muskmelon seedling growth were observed due to earlier germination, which gave the seedlings a longer time to develop (Nascimento \& West, 1999). Osmotic potential around $-1.30 \mathrm{MPa}$ in several solutions at $25^{\circ} \mathrm{C}$ is adequate for melon seed priming. Salt solutions may lead to a better germination rate, but may be deleterious for muskmelon seed germination.

Experiment 2: Although seeds had been previously treated with fungicide (Captan 50 WP at $3 \mathrm{~g}$ $\mathrm{kg}^{-1}$ of seed), those from aerated treatments had higher fungal growth during the germination test, especially at $17^{\circ} \mathrm{C}$ (data not shown). An increased microorganism population was also observed in aerated priming solution of cantaloupe seeds (Akers et al., 1985; Nascimento \& West, 1998a). SMC increased with priming duration until 12 days (Table 4). Seeds from aerated solutions tended to absorb more water during the soaking period, suggesting that oxygen enhances

Table 3 - Muskmelon seedling development after 10 days at 17 and $25^{\circ} \mathrm{C}$ in response to seed priming at different osmotic solutions and osmotic potentials.

\begin{tabular}{|c|c|c|c|c|c|c|c|c|c|}
\hline \multirow{3}{*}{ Osmotic Solution } & \multirow{3}{*}{$\begin{array}{c}\text { Osmotic } \\
\text { Potential } \\
\text { - MPa }\end{array}$} & \multicolumn{4}{|c|}{$17^{\circ} \mathrm{C}$} & \multicolumn{4}{|c|}{$25^{\circ} \mathrm{C}$} \\
\hline & & \multicolumn{2}{|c|}{ Root } & \multicolumn{2}{|c|}{ Shoot } & \multicolumn{2}{|c|}{ Root } & \multicolumn{2}{|c|}{ Shoot } \\
\hline & & length & $\mathrm{FW}^{*}$ & length & $\mathrm{FW}$ & length & FW & length & FW \\
\hline \multirow[t]{2}{*}{$\mathrm{KNO}_{3}$} & 1.06 & $6.2 \mathrm{ab}^{\star *}$ & $127 a b$ & $1.5 b$ & $387 a b$ & $10.0 \mathrm{ab}$ & $230 a$ & $6.0 \mathrm{a}$ & $1021 \mathrm{a}$ \\
\hline & 1.29 & $6.5 a b$ & $142 \mathrm{a}$ & $1.9 \mathrm{a}$ & $427 \mathrm{a}$ & $8.4 \mathrm{c}$ & $165 \mathrm{c}$ & $5.4 \mathrm{~cd}$ & $903 a$ \\
\hline \multirow[t]{2}{*}{$\mathrm{KH}_{2} \mathrm{PO}_{4}$} & 1.14 & $6.0 \mathrm{ab}$ & $127 a b$ & $1.1 \mathrm{cde}$ & $303 \mathrm{de}$ & $10.3 a$ & $195 a b c$ & $4.6 \mathrm{~cd}$ & $642 \mathrm{e}$ \\
\hline & 1.27 & $6.9 \mathrm{a}$ & $143 a$ & $1.2 \mathrm{bc}$ & $316 \mathrm{cde}$ & $10.5 a$ & 142 bc & $5.0 \mathrm{bc}$ & $767 \mathrm{~cd}$ \\
\hline \multirow[t]{2}{*}{$\mathrm{KNO}_{3}+\mathrm{KH}_{2} \mathrm{PO}_{4}$} & 1.18 & $5.9 a b c$ & $118 b c$ & $1.1 \mathrm{cde}$ & $341 \mathrm{bcd}$ & $9.2 \mathrm{abc}$ & $214 a b$ & $5.5 \mathrm{ab}$ & $805 \mathrm{bcd}$ \\
\hline & 1.32 & $5.8 \mathrm{bc}$ & 115 bc & $1.2 \mathrm{bcd}$ & $371 \mathrm{abc}$ & $9.4 \mathrm{abc}$ & $188 a b c$ & $5.9 \mathrm{ab}$ & 828 bc \\
\hline \multirow[t]{2}{*}{ Mannitol } & 1.27 & $4.5 d$ & $105 \mathrm{bcd}$ & 0.75 ef & 216 ef & $8.6 \mathrm{c}$ & $148 \mathrm{c}$ & $3.2 \mathrm{e}$ & $513 f$ \\
\hline & 1.36 & $5.1 \mathrm{~cd}$ & $111 \mathrm{bcd}$ & $0.84 \mathrm{def}$ & 268 ef & $9.5 \mathrm{abc}$ & $170 \mathrm{bc}$ & $4.0 \mathrm{de}$ & 605 ef \\
\hline \multirow[t]{2}{*}{ PEG } & 1.16 & $4.5 d$ & $101 \mathrm{~cd}$ & $0.56 \mathrm{f}$ & 262 ef & $9.7 \mathrm{abc}$ & $184 \mathrm{abc}$ & $4.0 \mathrm{de}$ & 577 ef \\
\hline & 1.53 & $4.5 d$ & $86 \mathrm{~d}$ & $0.53 \mathrm{f}$ & $220 \mathrm{f}$ & $9.4 \mathrm{abc}$ & $195 a b c$ & $3.8 \mathrm{de}$ & $692 \mathrm{de}$ \\
\hline Nonprimed & - & $5.1 \mathrm{~cd}$ & $107 \mathrm{bcd}$ & $0.57 \mathrm{f}$ & $221 \mathrm{f}$ & $8.8 \mathrm{bc}$ & $167 \mathrm{bc}$ & $3.8 \mathrm{de}$ & 604 ef \\
\hline
\end{tabular}

${ }^{*} \mathrm{FW}=$ Total fresh weight. Length $(\mathrm{cm})$ and fresh weight $(\mathrm{mg})$ of 20 seedlings randomly selected.

${ }^{* *}$ Values within a column followed by the same letter are not different $(P=0.05)$, according to Duncan's multiple range test. 
water uptake (Yeoung et al., 1995). Priming increased germination rate at both temperatures, although it was more evident at $17^{\circ} \mathrm{C}$. Increasing the soaking duration and including aeration improved the germination rate at $17^{\circ} \mathrm{C}$, but an interaction between these two factors was not observed (Table 5). Aeration also affected germination percentage for both temperatures. Soaking in aerated solution for 12 days was deleterious for seed germination. An increase of metabolism in aerated solutions, as well as possible salt penetration into the seeds during soaking might have caused the reduction of germination. Akers et al. (1985) reported deleterious effects of aerated salt $(\mathrm{NaCl})$ during cantaloupe seed priming. Shoot and root growth were greater in those treatments that exhibited faster germination (Table 6), suggesting that priming does not accelerate seedling growth, corroborating with the results of experiment 1.

Rapid seedling establishment might minimize crop risk due to environmental conditions or insect and disease problems during field emergence, which is another advantage of primed seeds in muskmelon, especially under adverse conditions. Rapid stand establishment may result in a shorter cycle, although no practical effect on earliness was observed in 'Roundpack' melon primed seeds (Passam et al., 1989). In addition, seed priming minimizes seed coat adherence during emergence of muskmelon seeds (Nascimento \& West, 1998b).

Aeration of soaking salt solution during muskmelon seed priming lead to faster germination. However, it may be deleterious for muskmelon seed germination due to increased fungal growth. Finally, seeds of priming treatments presented better seed germination, especially at low temperatures, and may have better seedling development.
Table 4 - Seed moisture content of muskmelon seeds in response to seed priming with and without aeration.

\begin{tabular}{lccc}
\hline \multirow{2}{*}{$\begin{array}{l}\text { Soaking } \\
\text { period }\end{array}$} & \multirow{2}{*}{ Aeration } & \multicolumn{2}{c}{ Moisture content (\%) } \\
\cline { 3 - 4 } days & After Priming & After Drying \\
\hline 3 & Yes & 41.7 & 6.8 \\
3 & No & 41.7 & 6.7 \\
6 & Yes & 41.9 & 6.7 \\
6 & No & 41.5 & 6.6 \\
9 & Yes & 43.6 & 6.7 \\
9 & No & 43.8 & 6.6 \\
12 & Yes & 42.2 & 6.7 \\
12 & No & 39.8 & 7.0 \\
Non primed & - & - & $5.8{ }^{*}$ \\
${ }^{*}$ Original seed moisture content. & &
\end{tabular}

Table 5 - Muskmelon seed germination at 17 and $25^{\circ} \mathrm{C}$ in response to seed priming duration and aeration.

\begin{tabular}{lccccc}
\hline \multirow{2}{*}{$\begin{array}{l}\text { Soaking } \\
\text { period }\end{array}$} & \multirow{2}{*}{ Aeration } & \multicolumn{2}{c}{$17^{\circ} \mathrm{C}$} & \multicolumn{2}{c}{$25^{\circ} \mathrm{C}$} \\
\cline { 3 - 6 } & & MGR $^{*}$ & Germ. & MGR $^{*}$ & Germ. \\
\hline days & Yays & $\%$ & days & $\%$ \\
3 & No & 2.9 & 91 & 1.0 & 99 \\
3 & Yes & 3.2 & 100 & 1.0 & 100 \\
6 & No & 3.5 & 99 & 1.0 & 100 \\
6 & Yes & 2.4 & 95 & 1.0 & 99 \\
9 & No & 3.2 & 99 & 1.0 & 100 \\
9 & Yes & 3.1 & 86 & 1.0 & 79 \\
12 & No & 4.5 & 97 & 1.1 & 99 \\
12 & - & 4.5 & 99 & 1.1 & 99 \\
Nonprimed & & $* *$ & NS & $* *$ & $* *$ \\
Duration (D) & & $* *$ & $* *$ & NS & $* *$ \\
Aeration (A) & & NS & NS & NS & $* *$ \\
D x A & & &
\end{tabular}

Ns, $\star \star * N o n s i g n i f i c a n t$ or significant at $P=0.01$, respectively. ${ }^{*} \mathrm{MGR}=$ average number of days to germinate.

Table 6 - Muskmelon seedling development at two temperatures in response to seed priming with and without aeration.

\begin{tabular}{|c|c|c|c|c|c|c|c|c|c|}
\hline \multirow{3}{*}{$\begin{array}{l}\text { Duration } \\
\text { (days) }\end{array}$} & \multirow{3}{*}{ Aeration } & \multicolumn{4}{|c|}{$17^{\circ} \mathrm{C}$} & \multicolumn{4}{|c|}{$25^{\circ} \mathrm{C}$} \\
\hline & & \multicolumn{2}{|c|}{ Root } & \multicolumn{2}{|c|}{ Shoot } & \multicolumn{2}{|c|}{ Root } & \multicolumn{2}{|c|}{ Shoot } \\
\hline & & Length & $\mathrm{FW}^{*}$ & length & $\mathrm{FW}^{*}$ & Length & $\mathrm{FW}^{*}$ & Length & $\mathrm{FW}^{*}$ \\
\hline 3 & Yes & 7.5 & 172 & 2.3 & 485 & 8.4 & 199 & 3.8 & 634 \\
\hline 3 & No & 6.9 & 186 & 2.2 & 473 & 7.7 & 199 & 4.1 & 731 \\
\hline 6 & Yes & 7.8 & 196 & 2.4 & 523 & 8.1 & 213 & 4.0 & 748 \\
\hline 6 & No & 6.1 & 177 & 2.0 & 473 & 8.0 & 206 & 4.1 & 694 \\
\hline 9 & Yes & 7.4 & 172 & 2.7 & 578 & 8.8 & 225 & 4.2 & 785 \\
\hline 9 & No & 6.2 & 170 & 2.2 & 428 & 7.6 & 182 & 3.5 & 677 \\
\hline 12 & Yes & 7.1 & 179 & 2.2 & 526 & 7.8 & 184 & 3.6 & 636 \\
\hline 12 & No & 6.7 & 167 & 1.9 & 487 & 7.5 & 191 & 4.0 & 684 \\
\hline Non primed & - & 5.8 & 145 & 0.9 & 294 & 8.3 & 212 & 2.9 & 507 \\
\hline Duration (D) & & NS & NS & NS & NS & NS & NS & NS & NS \\
\hline Aeration $(\mathrm{A})$ & & $* *$ & NS & $* *$ & $* *$ & NS & NS & NS & NS \\
\hline$D \times A$ & & NS & NS & NS & NS & NS & NS & NS & NS \\
\hline
\end{tabular}

*Length $(\mathrm{cm})$ and fresh weight - FW $(\mathrm{mg})$ of 20 seedlings.

NS, **Nonsignificant or significant at $P=0.01$, respectively. 


\section{REFERENCES}

AKERS, S.W.; BREDE, J.; BATES, J.J. Why some vegetable seed cannot be primed in aerated solutions. HortScience, v.20, p.549, 1985.

ALVARADO, A.D.; BRADFORD, K.J.; HEWITT, J.D. Osmotic priming of tomato seeds: Effects on germination, field emergence, seedling growth, and fruit yield. Journal of American Society for Horticultural Science, v.112, p.427-432, 1987.

ASSOCIATION OF OFFICIAL SEED ANALYSIS. Rules for testing seeds. Journal of Seed Technology, v.16, p.1-113, 1993.

BRADFORD, K.J. Seed priming improves germination and emergence of cantaloupe at low temperature. HortScience, Alexandria, v. 20, p. 598, 1985.

BRADFORD, K.J. Manipulation of seed water relations via osmotic priming to improve germination under stress conditions. HortScience, v.21, p.11051112, 1986.

BRADFORD, K.J.; MAY, D.M.; HOYLE, B.J.; SIBINSKI, S.; SCOTT, S.J.; TYLER, K.B. Seed and soil treatments to improve emergence of muskmelon from cold or crusted soils. Crop Science, v.28, p.1001-1005, 1988.

BRAY, C.M. Biochemical processes during the osmopriming of seeds. In: KIGEL, J.; GALILI, G. (Ed.) Seed development and germination. New York: Marcel Dekker, 1995. p.767-789.

BROCKLEHURST, P.A.; DEARMAN, J. A comparison of different chemicals for osmotic treatment of vegetable seed. Annals of Applied Biology v. 105, p.391-398, 1984

BUJALSKI, W.; NIENOW, A.W.; GRAY, D. Establishing the large scale osmotic priming of onion seeds using enriched air. Annals of Applied Biology, v.115, p.171-176, 1989

CANTLIFFE, D.J.; ELBALA, M.; GUEDES, A.C.; ODELL, G.B.; PERKINSVEAZIE, P.; SCHULTHEIS, J.R.; SEALE, D.N.; SHULER, K.D.; TANNE, I.; WATKINS, J.T. Improving stand establishment of direct-seeded vegetables in Florida. Proceedings of Florida State Horticutural Society, v.100, p.213-216, 1981

CARPENTER, W.J.; BOUCHER, J.F. Priming improves high-temperature germination on pansy seed. HortScience, v.26, p.1483-1485, 1991.

DHILLON, N.P.S. Seed priming of male sterile muskmelon (Cucumis melo L. ) for low temperature germination. Seed Science \& Technology, v.23, p.881-884, 1995.

GUEDES, A.C.; CANTLIFFE, D..J. Germination of lettuce seeds at high temperature after seed priming. Journal of American Society for Horticultural Science, v.105, p.777-781, 1980.
GUEDES, A.C.; CANTLIFFE, D..J.; SHULER, K.D.; MUNTER, E. Overcoming thermodormancy in lettuce by seed priming. Proceedings of Florida State Horticutural Society, v.92, p.130-133, 1979.

HEYDECKER, W.; HIGGIS, J.; TURNER, Y.J. Invigoration of seeds. Seed Science \& Technology, v.3, p.881-888, 1975

MURRAY, G.A. Osmoconditioning carrot seed for improved emergence. HortScience, v.24, p.701, 1989.

NASCIMENTO, W.M.; WEST, S.H. Microorganism growth during muskmelon seed priming. Seed Science \& Technology, v.26, p.531-534, 1998a.

NASCIMENTO, W.M.; WEST, S.H. Priming and seed orientation affect emergence, seedcoat adherence and seedling development of muskmelon transplants. HortScience, v.33, p.847-848, 1998b.

NASCIMENTO, W.M.; WEST, S.H. Muskmelon transplant production in response to seed priming. HorTechnology, v.9, p.53-55, 1999.

NASCIMENTO, W.M.; WEST, S.H. Drying during muskmelon (Cucumis melo L.) seed priming and its effects on seed germination and deterioration. Seed Science \& Technology, v.28, p.211-215, 2000.

NERSON, H.; GOVERS, A. Salt priming of muskmelon seeds for low temperature germination. Scientia Horticulturae, v.28, p.85-91, 1986.

O'SULLIVAN, J.; BOUW, W.J. Pepper seed treatment for low-temperature germination. Canadian Journal of Plant Science, v.64, p.387-393, 1984.

PARERA, C.A.; CANTLIFFE, D.J. Presowing seed priming. Horticultural Reviews, v.16, p.109-139, 1994.

PASSAM, H.C.; KARAVITES, P.I.; PAPANDREOU, A.A.; THANOS, C.A.; GEORGHIOU, K. Osmoconditioning of seeds in relation to growth and fruit yield of aubergine, pepper, cucumber and melon in unheated greenhouse cultivation. Scientia Horticulturae, v.38, p.217-216, 1989.

SMITH, P.T.; COBB, B.G. Accelerated germination of pepper seed by priming with salt solutions and water. HortScience, v.26, p.417-419, 1991.

WELBAUM, G.E.; BRADFORD, K.J. Water relations of seed development and germination in muskmelon (Cucumis melo L.). IV. Characteristics of the perisperm during seed development. Plant Physiology, v.92, p.10381045, 1989.

YEOUNG, Y.R.; WILSON JR., D.O.; MURRAY, G.A. Oxygen regulates imbibition of muskmelon seeds. Seed Science \& Technology, v.23, p.843 850, 1995.

YEOUNG, Y.R.; WILSON JR., D.O.; MURRAY, G.A. Germination performance and loss of late-embryogenesis-abundant (LEA) proteins during muskmelon seed priming. Seed Science \& Technology, v.24, p.429-439, 1996.

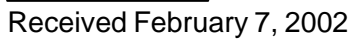

